\title{
An Experimental Study on Thermal Damage and Spalling of Concrete Under Loading Conditions in a Tunnel Fire
}

\author{
Hyung-Jun Kim ${ }^{1}$, Heung-Youl Kim*², Jae-Sung Lee ${ }^{3}$ and Ki-Hyuk Kwan ${ }^{4}$ \\ ${ }^{1}$ Researcher, Fire Safety Research, Korea Institute of Construction Technology, Korea \\ ${ }^{2}$ Fellow Researcher, Fire Safety Research, Korea Institute of Construction Technology, Korea \\ ${ }^{3}$ Professor, Department of Architectural Engineering, Hannam University, Korea \\ ${ }^{4}$ Professor, Department of Architectural Engineering, University of Seoul, Korea
}

\begin{abstract}
While fire outbreaks in tunnels are not as frequent as those in other structures, temperature rises up to over $1,000^{\circ} \mathrm{C}$ within 5 minutes upon the outbreak of a fire in a tunnel due to its semi-closed structure. Temperature rise in a concrete structure caused by a fire under constant load leads to deterioration in strength, accelerates deformation and finally results in collapse. In this study to identify structural damage caused by a fire in a tunnel, fire tests were conducted using a heating furnace that satisfied the KS F 2257-1 and EFNARC regulations to evaluate the thermal damage to a tunnel concrete lining. The two objects of the test were: 1) to identify the thermal damage to concrete lining associated with fire intensity 2) to evaluate the characteristics of spalling and failure of concrete lining associated with load ratio. The range of thermal damage under the ISO fire, heating rate of $1^{\circ} \mathrm{C} / \mathrm{Sec}$., MHC fire ${ }^{3)}$ and RWS fire ${ }^{3)}$ was $30 \mathrm{~mm}, 20 \mathrm{~mm}, 100 \mathrm{~mm}$ and $50 \mathrm{~mm}$, respectively. The depth of spalling in the RWS and MHC fires was $30 \mathrm{~mm}$. Spalling was observed under unstressed conditions, while it was not observed under $20 \sim 40 \%$ loads because of the smooth flow of vapors enabled by micro cracks. Under $70 \%$ load, the rapid spread of cracks caused failure during 10 minutes of heating.
\end{abstract}

Keywords: tunnel fire; heating rate; spalling; fire damage range

\section{Introduction}

Tunnels are being built longer and the frequency of vehicles' passing through them is also increasing. Gases and heat used to be the main causes of fire outbreaks in tunnels; however, the influence of fire load has emerged as one of the important factors due to the increase of vehicles and diversification of goods associated with technological advance. Upon a fire outbreak in a tunnel, temperature changes more rapidly than forecasted in fire-resistance design, which causes the fire to last longer than expected, resulting in a disaster and tremendous restoration costs. The EURO Tunnel fire (1996, lasting for 3 days), Mont Blanc Tunnel fire (1999, lasting for 53 hours), Moorfleet Underpass fire in Hamburg, Germany (destroying $34 \mathrm{~m}$ of PSC lining and causing $30 \mathrm{~cm}$ spalling), Guadarrama

\footnotetext{
*Contact Author: Heung-Youl Kim, Fellow Researcher,

Fire Safety Research Division, Korea Institute of Construction Technology, 1190, Simindae-Ro, Ilsanseo-Gu, Goyang-Si, Gyeonggi-Do, 411-712, Korea

Tel: +82-31-369-0507 Fax: +82-31-369-0540

E-mail: hykim@kict.re.kr

(Received October 8, 2010 ; accepted August 11, 2011)
}

Underpass fire in Spain (Damaging 120m-long lighting, fire-extinguishing facilities and tunnel facilities), subway fire in Daegu, Korea (resulting in 197 casualties and property loss of KW 4.7 billion) and Guma-Dansung Tunnel fire in Korea (generating 600 $900^{\circ} \mathrm{C}$ water heat and damaging $400 \mathrm{~m}$ long wall tiles) are examples of large-scale fires in tunnels. ${ }^{1)}$

Upon the outbreak of a fire in a tunnel, the temperature rises rapidly due to its semi-closed structure, and spalling of the concrete lining causes sectional damage. Therefore, the damage to concrete lining caused by a fire in a tunnel and its thermal characteristics should be closely examined. In this study, the two tests were conducted to identify the thermal damage to concrete lining associated with fire intensity and to evaluate the characteristics of spalling and failure of concrete lining associated with load ratio.

\section{Scope of the Study}

The selection of test variables is important in clearly identifying the characteristics of spalling upon the outbreak of a fire in a tunnel because spalling is attributable to multiple and various causes. Test variables in this study were selected based on a 
case study consisting of a comparison and analysis of documents covering the influential factors on spalling. ${ }^{2}$ The damage to concrete lining was analyzed based on the ITA permissible temperature limit since quantitative analysis of the damage upon the outbreak of fire in a tunnel is required in order to decide whether tunnels should be designed for fire-resistance and to what extent they should be fire-protected. ${ }^{3)}$

The test conducted in this study consisted of 2 parts as follows.

The first part was for identifying thermal damage to concrete lining associated with fire intensity. The ISO, MHC (Modified Hydrocarbon) and RWS (Rijks Water Staat) scenarios for fire outbreaks in tunnels provided by the PIARC and the fire scenario with a heating rate of $1^{\circ} \mathrm{C} / \mathrm{sec}$ (maximum of $700^{\circ} \mathrm{C}$ ) were used to analyze the influence of fire intensity on the characteristics of spalling. ${ }^{4)}$

The second part was for analyzing the spalling and failure mode of concrete lining associated with different load ratios. Load ratios of 0, 20, 40, 60 and $70 \%$ were applied under the condition of the MHC fire to identify the influence of load ratio on concrete spalling and thermal characteristics of the damaged area. Fig.1. shows the process of the study.

\section{Heating Furnace Performance 3.1 Features \& Details}

Photo 2. shows the heating furnace used in the test to secure the implementation of heating curves for each variable.

The deviation of furnace temperature was set to comply with the KS F $2257-1^{5)}$ and EFNARC ${ }^{6}$ standards in order to secure the reliability of heating capacity in analyzing the behavior of concrete under high temperatures. In order to implement various tunnel fire scenarios, temperature can be adjusted up to 99 points. The internal space of the furnace was protected with fireproof material (ISO Wool Ceramic Fiber 1260 Board) to implement a maximum temperature of over $1,350^{\circ} \mathrm{C}$.

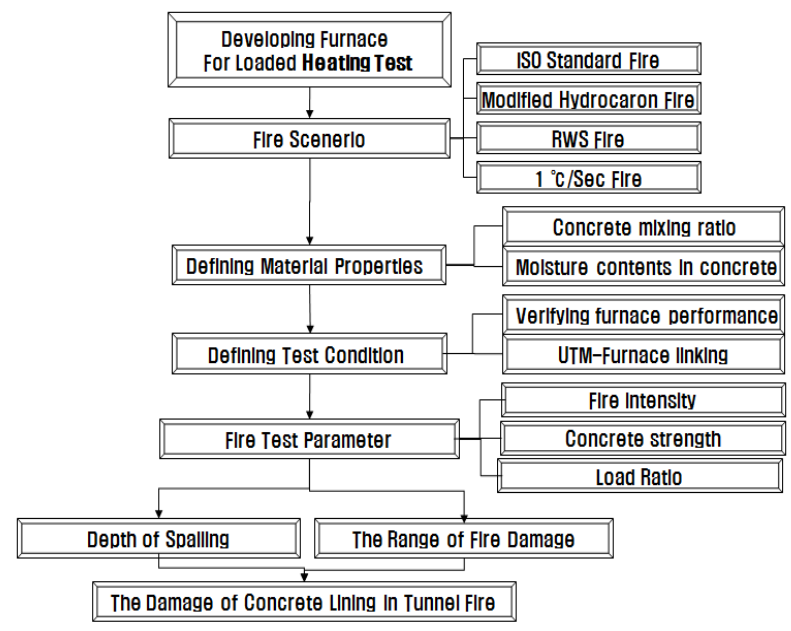

Fig.1. The Process of the Study

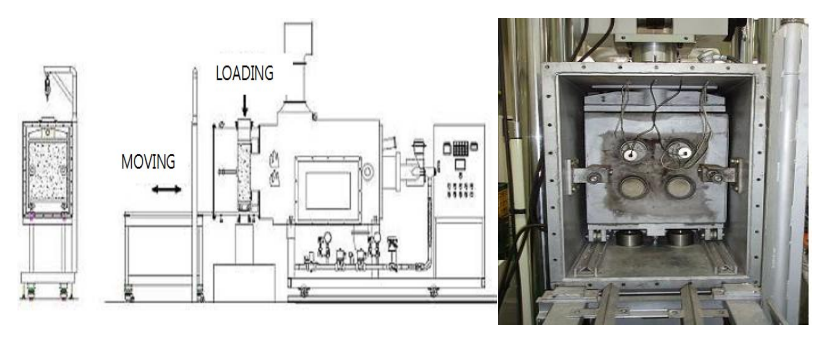

Photo 2. The Shape of Fire Test Furnace

R-type thermo couples were set up inside the heating furnace and sheath thermo couples were used to solve the problem of the increase in deviation caused by consecutive operations.

The thermo couples were set up at constant intervals in order to measure average inside temperature near the specimens in compliance with the KS F 2257 and EFNARC standards. In order to prevent thermo couples from being directly exposed to flames inside the furnace, they were set up at least $450 \mathrm{~mm}$ away from the walls, floor and ceiling of the heating furnace and $102 \mathrm{~mm}$ away from the heating surface of the specimen in accordance with the EFNARC $(100 \pm 5 \mathrm{~mm})$

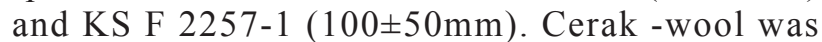
attached between the specimens and heating furnace in order to prevent heat outflow at the back side of the specimens and a thermal expansion confinement condition was provided for the non-heated area of the specimens so that they would adhere to the heating furnace. A pulley was used to place heavy specimens in the heating furnace and a rail was used to move them to the heating surface.

\subsection{Verification of heating furnace performance}

The calibration of the heating furnace was conducted in accordance with the KS F 2257-1 (ISO 834-1) and EFNARC standards as shown in Table 1. The KS F 2257-1 (ISO 834-1) and EFNARC standards were used to evaluate the performance of heating furnace against the fire curve applied in this test. The limits of percentage deviation in the furnace temperature are as follows.
a) $5<\mathrm{t}<10$ minutes: $\mathrm{de} \leq 15 \%$
b) $10<\mathrm{t} \leq 30$ minutes: $\mathrm{de}=\{15-0.5(\mathrm{t}-10)\} \%$
c) $30<\mathrm{t} \leq 60: \mathrm{de}=\{5-0.083(\mathrm{t}-30)\} \%$
d) $60<\mathrm{t}: \mathrm{de}=2.5 \%$

The adjustment test to secure the reliability of heating furnace performance provided a maximum error of $14.2 \%$ meaning that it met the performance requirement. Showing a deviation of less than $6 \%$ in all sections as shown in Table 1., it also met the requirement of the scenarios for fire outbreaks in tunnels prescribed by the PIARC.

\subsection{Loading-Heating linkage}

The purpose of this study was to analyze thermal damage and spalling of concrete caused by in-plane compression loads under the most deadly scenario for fire outbreaks in tunnels and find the load ratio at which the deterioration in strength of concrete lining 
Table 1. Calibration Result of Furnace (\%)

\begin{tabular}{c|c|c|c|c|c}
\hline \multicolumn{2}{c|}{ Standard (Range) } & ISO & MHC & $1^{\circ} \mathrm{C} / \mathrm{SEC}$ & RWS \\
\hline \multirow{2}{*}{$5-10$ minutes } & Lowest & -2.0 & -5.4 & -14.2 & -6.1 \\
\cline { 2 - 6 } & Highest & 0.6 & 3.4 & 14.0 & -0.4 \\
\hline \multirow{2}{*}{$\begin{array}{c}10-30 \\
\text { minutes }\end{array}$} & Lowest & -1.8 & -4.3 & -10.5 & -0.01 \\
\cline { 2 - 6 } & Highest & 0.2 & 3.7 & 9.5 & -0.0 \\
\hline $\begin{array}{c}30-60 \\
\text { minutes }\end{array}$ & Lowest & -2.2 & -3.5 & -4.5 & -1.0 \\
\cline { 2 - 6 } & Highest & 0.09 & 2.8 & 6.6 & 0.1 \\
\hline \multirow{2}{*}{$\begin{array}{c}\text { After 60 } \\
\text { minutes }\end{array}$} & Lowest & -1.5 & -4.3 & -4.0 & -0.9 \\
\cline { 2 - 6 } & Highest & 0.3 & 3.3 & 7.3 & 0.2 \\
\hline
\end{tabular}

attributable to a fire finally resulted in its failure. For this, the heating furnace ${ }^{7)}$ shown in Photo 2 . was used for the loaded heating test to provide the condition of a fire outbreak in a tunnel characterized by simultaneous attack of load and heat.

\section{Test Plan}

Table 2. shows the test variables used to analyze the influence of various fire conditions, design compressive strengths and load conditions on thermal damage and spalling of concrete lining.

Table 2. Test Variables of Concrete Lining

\begin{tabular}{|c|c|c|c|c|c|}
\hline Specimen & $\begin{array}{c}\text { Fire } \\
\text { Scenario }\end{array}$ & $\begin{array}{l}\text { Strength } \\
(\mathrm{MPa})\end{array}$ & $\begin{array}{l}\text { Size } \\
(\mathrm{mm})\end{array}$ & \begin{tabular}{|c|} 
Thermo- \\
Couple $(\mathrm{mm})$
\end{tabular} & $\begin{array}{c}\text { Load } \\
\text { Ratio (\%) }\end{array}$ \\
\hline S-1 & ISO & \multirow{4}{*}{40} & \multirow{4}{*}{$600 \times 600 \times 200$} & \multirow{4}{*}{$\begin{array}{l}5,10,20,30 \\
50,100,150\end{array}$} & \multirow{4}{*}{0} \\
\hline S-2 & MHC & & & & \\
\hline S-3 & $\mathrm{S}-1^{\circ} \mathrm{C}-1$ & & & & \\
\hline S-4 & RWS & & & & \\
\hline I-M-1 & \multirow{5}{*}{ MHC } & \multirow{5}{*}{24} & \multirow{5}{*}{$600 \times 600 \times 150$} & \multirow{5}{*}{$\begin{array}{l}10,20,30 \\
40,50,75\end{array}$} & 0 \\
\hline I-M-2 & & & & & 20 \\
\hline I-M-3 & & & & & 40 \\
\hline I-M-4 & & & & & 60 \\
\hline I-M-5 & & & & & 70 \\
\hline
\end{tabular}

\subsection{Test variables and specimen fabrication}

\subsubsection{Specimen size}

Specimens were manufactured as shown in photo 3 considering sensor locations for each variable. The sizes of the specimens were $600 \mathrm{~mm} \times 600 \mathrm{~mm} \times$ $150 \mathrm{~mm}$ and $600 \mathrm{~mm} \times 600 \mathrm{~mm} \times 200 \mathrm{~mm}$. In order to minimize heat conduction at the loading point of the UTM (Universal Testing Machine), a 100mm distance was provided for each of the 4 sides as a buffer against concrete heat conduction so that heat conduction at the loading point could be controlled at the directly heated area $(400 \mathrm{~mm} \times 400 \mathrm{~mm})$. The configuration of the heated area complied with the small-scale test standards provided by the EFNARC and fire-proofing material was not used in the specimens.

4.1.2 Selection of fire scenario (fire intensity)

In order to provide various fire intensities, four fire scenarios consisting of the ISO fire, MHC (Modified Hydrocarbon) fire, heating rate $1^{\circ} \mathrm{C} / \mathrm{SEC}$ and RWS fire were used to analyze the damage to concrete as shown in Fig.4.

Based on "ISO Fire" and featuring typical temperature rise, the ISO fire curve is closer to fire outbreaks in buildings than those in tunnels. Mainly used in standard fire tests, it is used as an international

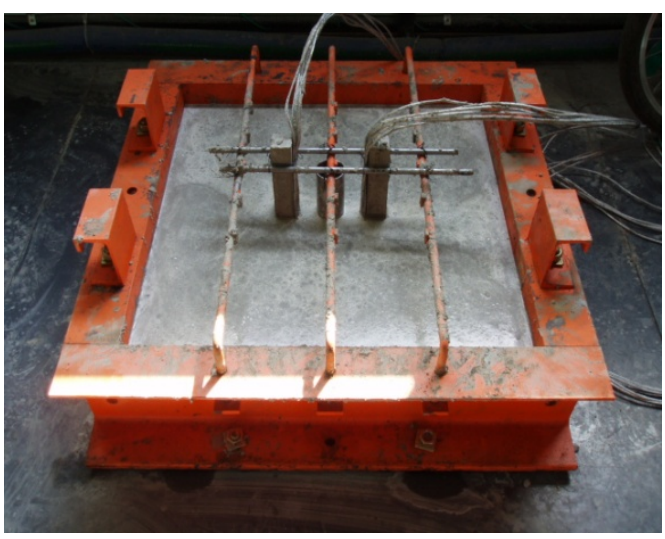

Photo 3. Manufacture of Test Specimen

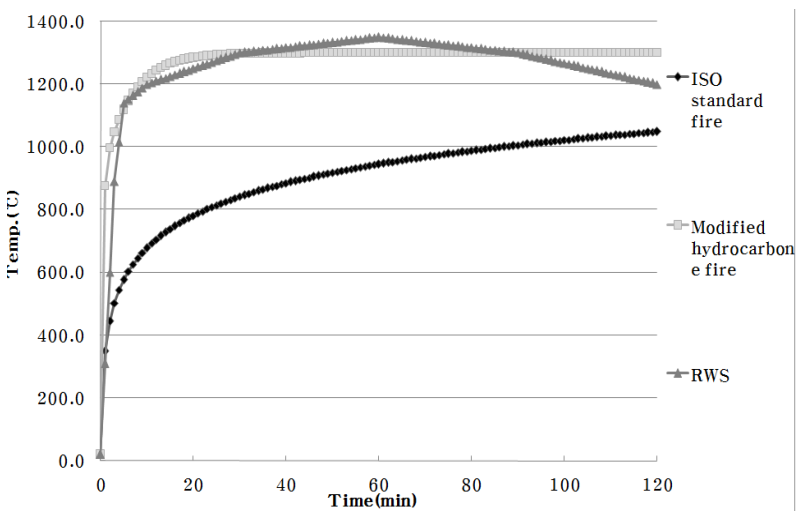

Fig.4. Fire Scenario of Test

-standard fire curve. In this study, it was applied to the test to provide the condition of a small-scale fire in a tunnel caused by cars. Made by the adjustment of the heating ratio of hydrocarbon, the MHC fire is a scenario to analyze the thermal shock to concrete caused by the rapid temperature rise at the beginning stage. In this study, it was used to analyze temperature distribution associated with pore pressure and the depth of the heated area. The fire curve with $1{ }^{\circ} \mathrm{C} / \mathrm{SEC}$ was used to identify the influence of low heating ratio and constant temperature $\left(680^{\circ} \mathrm{C}\right)$ on spalling.

The temperature was raised by $1{ }^{\circ} \mathrm{C}$ per second to reach $680^{\circ} \mathrm{C}$ in 11 minutes, after which it remained constant to observe the influence of the heating ratio. The RWS fire curve is the worst scenario of a fire in an oil tanker where 300 MW load lasts for 120 minutes. The PIARC considers it to have the same intensity as the MHC fire. These scenarios for fire outbreaks in tunnels featuring various fire intensities were applied to the experiment to analyze their influence on spalling and the thermal damage to concrete lining.

\subsubsection{Thermo couple set up}

K-type thermo couples were set up at a depth of $5,10,20,30,50,100$ and $150 \mathrm{~mm}$ at the left side and $10,30,40,50$ and $75 \mathrm{~mm}$ at the right side as shown in Fig.5. to measure the temperatures inside the concrete and analyze heat transfer characteristics associated with the depth of the heated area. In order to secure the 
preciseness of the thermo couples measurement depth, thermo couple setup samples $45 \mathrm{~mm}$ x $45 \mathrm{~mm} \times 150 \mathrm{~mm}$ and $45 \mathrm{~mm} \times 45 \mathrm{~mm} \times 200 \mathrm{~mm}$ in dimension were manufactured with identical mixing ratio and fixed into a specimen mold to produce specimens.

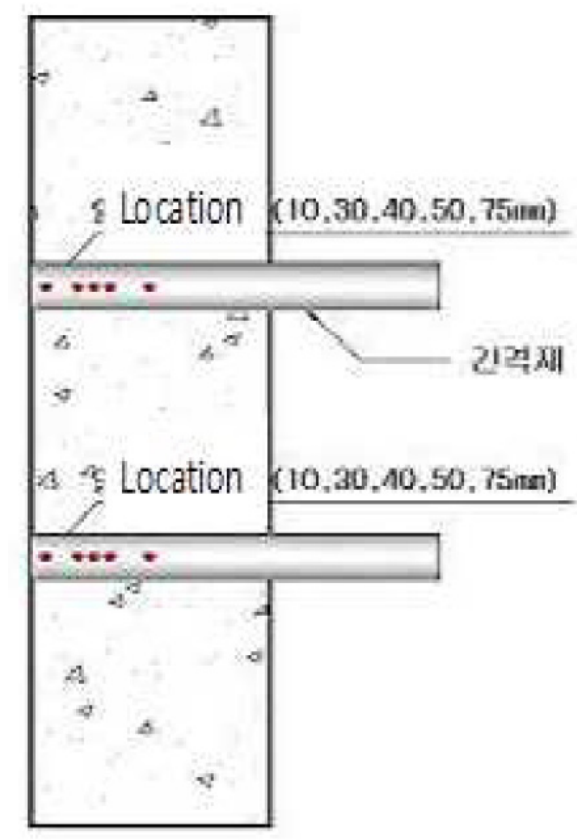

Fig.5. Installation of Thermal Couple

\subsection{Mixing ratio and material properties of concrete lining}

4.2.1 Concrete mixing ratio and properties

The fire-resistance of concrete exposed to a fire depends on multiple factors such as aggregate properties, concrete mixing ratio, water content, pore pressure, load, heating method and maximum heat capacity.

The standard for tunnel design provided by the Korean Ministry of Land, Transport \& Maritime Affairs prescribes that while concrete with a strength of $21 \sim 24 \mathrm{MPa}$ on the 28th day of curing should be used, high-strength concrete can be also used. ${ }^{8)}$ Thus, $24 \mathrm{MPa}$ concrete relatively vulnerable to spalling and thermal damage was mixed with $40 \mathrm{MPa}$ concrete to manufacture specimens for the test. Three kinds of Korean-made rapid hardening portland cement satisfying the requirement of the KS L 52019) Portland Cement Regulation were used. Tables 3. and 4. show the material properties of the aggregates and mixing ratio and material test result, respectively.

\subsubsection{Measurement of water-content inside concrete}

Moisture content in concrete is the main cause of spalling. The higher the percentage of water content is, the higher the possibility of spalling is because the water inside concrete raises water vapor pressure and pore pressure. The water inside concrete consists of free water and bound water. Since the water vaporizing up to $100 \sim 150^{\circ} \mathrm{C}$ is mainly free water,
Table 3. Material Properties of Coarse

\begin{tabular}{c|c|c|c|c|c}
\hline Aggregate & $\begin{array}{c}\text { Density } \\
\left(\mathrm{t} / \mathrm{m}^{3}\right)\end{array}$ & $\begin{array}{c}\text { Fineness } \\
\left(\mathrm{g} / \mathrm{cm}^{3}\right)\end{array}$ & $\begin{array}{c}\text { Absorption } \\
(\%)\end{array}$ & $\begin{array}{c}\text { Passing } 0.08 \mathrm{~mm} \\
\text { sieve }(\%)\end{array}$ & $\begin{array}{c}\mathrm{FM} \\
(\%)\end{array}$ \\
\hline $\mathrm{S}$ & 1.57 & 2.58 & 1.62 & 1.9 & 2.89 \\
\hline $\mathrm{G}$ & 1.56 & 2.62 & 0.65 & 0.2 & 6.59 \\
\hline
\end{tabular}

Table 4. Mixing Ratio of Concrete Lining

\begin{tabular}{c|c|c|c|c|c|c|c}
\hline \multirow{2}{*}{$\begin{array}{c}\mathrm{f}_{\text {ck }} \\
(\mathrm{MPa})\end{array}$} & \multirow{2}{*}{$\begin{array}{c}\mathrm{W} / \mathrm{C} \\
(\%)\end{array}$} & \multirow{2}{*}{$\begin{array}{c}\mathrm{S} / \mathrm{a} \\
(\%)\end{array}$} & \multicolumn{5}{|c}{ Unit content $\left(\mathrm{kg} / \mathrm{m}^{3}\right)$} \\
\cline { 4 - 8 } & & & Cement & Sand & $\begin{array}{c}\text { Gravel } \\
(19)\end{array}$ & Water & $\begin{array}{c}\text { Super } \\
\text { Plasticizer(\%) }\end{array}$ \\
\hline 24 & 47.2 & 46.8 & 341 & 874 & 993 & 161 & 1.02 \\
\hline 40 & 39.4 & 39.2 & 405.7 & 676.5 & 1066.1 & 159.8 & 6.5 \\
\hline
\end{tabular}

it is the principal cause of spalling. Consequently, the material properties of concrete should be defined through the measurement of water content in it to analyze its behavior upon a fire. In addition, data based on a reliable measuring method should be provided to identify the influence associated with it.

Methods to measure the percentage of water content inside concrete include the ASTM method, nuclear magnetism method, supersonic method and electro -magnetic method ${ }^{10)}$. In this study, the ASTM C 5669 ${ }^{11)}$ was used to measure the percentage of water content and the VAISALA was used to measure the relative and absolute humidity of 3 . Table 5 . is the summary of water content and relative humidity.

Table 5. Moisture Content of Concrete Lining

\begin{tabular}{c|c|c}
\hline Measurement & Item & Result \\
\hline \multirow{2}{*}{ ASTM C 566 } & Water vaporization $(\mathrm{g})$ & 142 \\
\cline { 2 - 3 } & Water content $(\%)$ & 3.73 \\
\hline VAISALA & Absolute humidity $\left(\mathrm{kg} / \mathrm{m}^{3}\right)$ & 11.7 \\
\cline { 2 - 3 } HM 44 & Relative humidity $(\%)$ & 98.5 \\
\hline
\end{tabular}

4.2.3 Measurement of the Inner Pore Pressure of the Concrete

The authors carried out a verifying test to discover whether the inner pore pressure changed in the different depths of the heating surface of the concrete, and the correlativity between the time and the temperature at the point of maximum pressure. Table 6 . shows the results. In the case of the ISO Fire, spalling appeared at an internal temperature of about $150 \sim 200^{\circ} \mathrm{C}$, and the maximum pore pressures of $0.821 \mathrm{MPa}$ and $0.756 \mathrm{MPa}$ were measured at a depth of $20 \mathrm{~mm}$ and $30 \mathrm{~mm}$. In the case of the MHC Fire, a relatively higher temperature appeared around a depth of $20 \mathrm{~mm}$ from the heating surface compared with that of the maximum pore pressure.

Table 6. Results of Pore Pressure

\begin{tabular}{c|c|c|c|c}
\hline Fire Intensity & $\begin{array}{c}\text { Depth } \\
(\mathrm{mm})\end{array}$ & $\begin{array}{c}\text { Maximum Pressure } \\
(\mathrm{MPa})\end{array}$ & $\begin{array}{c}\text { Time } \\
(\text { minute })\end{array}$ & $\begin{array}{c}\text { Temperature } \\
\left({ }^{\circ} \mathrm{C}\right)\end{array}$ \\
\hline \multirow{4}{*}{ ISO Fire } & 20 & 0.821 & 23 & 157 \\
\cline { 2 - 5 } & 30 & 0.756 & 53 & 185 \\
\cline { 2 - 5 } & 40 & 0.496 & 61 & 163 \\
\cline { 2 - 5 } & 50 & 0.574 & 58 & 168 \\
\hline \multirow{4}{*}{ MHC Fire } & 20 & 0.176 & 25 & 301 \\
\cline { 2 - 5 } & 30 & 0.205 & 18 & 170 \\
\cline { 2 - 5 } & 40 & 0.79 & 35 & 234 \\
\cline { 2 - 5 } & 50 & 0.368 & 29 & 176 \\
\hline
\end{tabular}




\section{Fire Test with Variables}

\subsection{Thermal damage and spalling associated with}

fire intensity

5.1.1 Influence on the depth of spalling

Photo 6.(a) shows the concrete exposed to the ISO fire. The maximum depth of spalling was $10 \mathrm{~mm}$. Photo 6.(b) is the concrete exposed to the MHC fire. The depth of spalling was $30 \mathrm{~mm}$. It is deduced that rapid rise in temperature at the early stage of a fire caused sectional damage and deeper spalling. While pore pressure was the greatest at $40 \mathrm{~mm}$, the deepest spalling was $30 \mathrm{~mm}$. As shown in Photo 6.(c), spalling of concrete was not observed when it was exposed to the $1^{\circ} \mathrm{C} / \mathrm{SEC}$ fire seemingly because the heating ratio was relatively low and the temperature remained constant at $680^{\circ} \mathrm{C}$ after the 11-minute point. Photo 6.(d) shows the concrete exposed to the RWS fire. The deepest spalling was $30 \mathrm{~mm}$ as in the MHC fire, seemingly because while the temperature in the RWS fire did not rise as rapidly as in the MHC fire, their temperature rise curves were similar to each other.

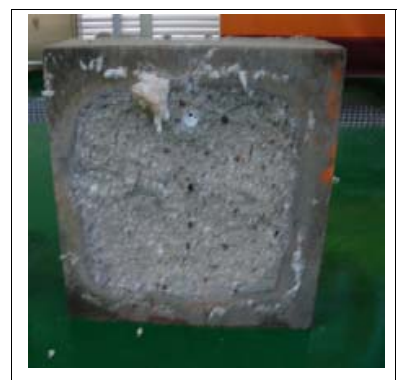

(a) ISO Fire

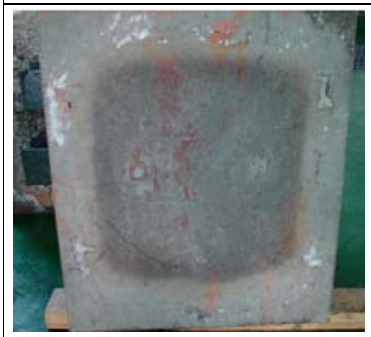

(c) $1{ }^{\circ} \mathrm{C} / \mathrm{SEC}$

Photo 6. Spalling Condition after Heating

\subsubsection{The range of thermal damage to concrete}

The ITA (International Tunneling Association) provides tunnel standards in terms of heat emission and fire duration to protect structures from fire outbreaks in tunnels. It suggests a permissible temperature limit of $380^{\circ} \mathrm{C}$ to prevent deterioration in the capacity of PC panel lining. Accordingly, the range of thermal damage to PC panel lining in each fire intensity (scenario) was obtained based on the standard as shown in Table 7 .

In the ISO fire, the concrete temperature at a depth of $5 \sim 20 \mathrm{~mm}$ rose rapidly in $20 \sim 30$ minutes. The highest pore pressure observed at a depth of $20 \mathrm{~mm}$ at this point in time indicated that concrete spalling occurred then. As the temperature rose over the ITA's permissible
Table 7. Fire Damage Range of Concrete Lining

\begin{tabular}{c|c|c|c}
\hline \multirow{2}{*}{ Lining } & $\begin{array}{c}\text { Fire Scenario } \\
(2 \text { hour })\end{array}$ & Spalling Depth $(\mathrm{mm})$ & $\begin{array}{c}\text { Fire Damage } \\
\left(380^{\circ} \mathrm{C}, \mathrm{mm}\right)\end{array}$ \\
\hline \multirow{2}{*}{$40 \mathrm{MPa}$} & ISO & 10 & $0 \sim 30$ \\
\cline { 2 - 4 } & $\mathrm{MHC}$ & 30 & $0 \sim 100$ \\
\cline { 2 - 4 } $\mathrm{D}-200 \mathrm{~mm}$ & $\mathrm{~S}-1^{\circ} \mathrm{C}-1$ & 0 & $0 \sim 20$ \\
\cline { 2 - 4 } & $\mathrm{RWS}$ & 30 & $0 \sim 50$ \\
\hline
\end{tabular}

limit $\left(380^{\circ} \mathrm{C}\right)$, the range of capacity deterioration was 0 $\sim 30 \mathrm{~mm}$ as shown in Fig.7.

In the MHC fire, rapid temperature rise caused spalling up to a depth of $30 \mathrm{~mm}$ seemingly at approximately the 10 -minute point. A rise in pore pressure at a depth of $40 \mathrm{~mm}$ from the heating surface indicated the formation of a vapor zone at a depth of $30 \sim 40 \mathrm{~mm}$, which caused spalling. As shown in Fig.8., capacity deterioration seemed feasible at the $100 \mathrm{~mm}$ point from the heating surface where the temperature was over the ITA's permissible limit of $380^{\circ} \mathrm{C}$.

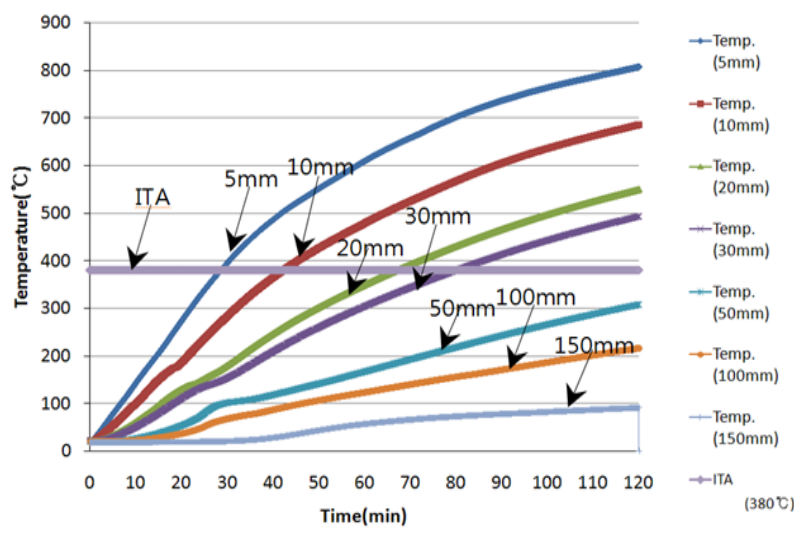

Fig.7. Fire Damage Range by ISO Fire $\left(380^{\circ} \mathrm{C}\right)$

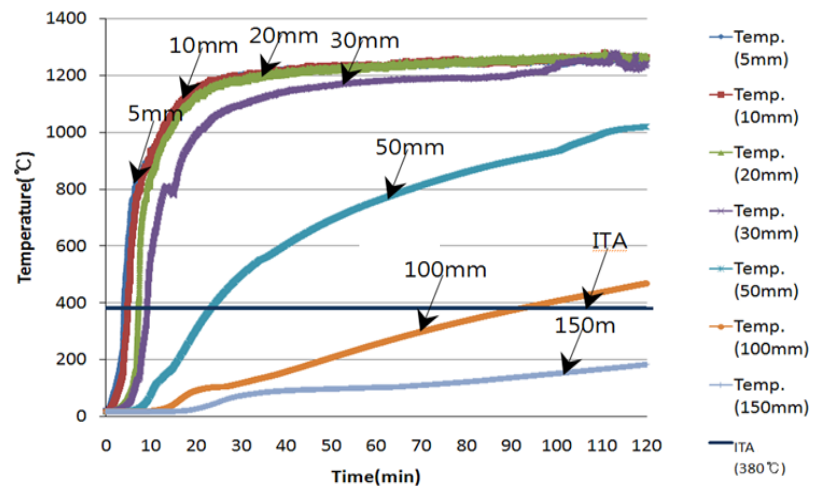

Fig.8. Fire Damage Range by MHC Fire $\left(380^{\circ} \mathrm{C}\right)$

In the $1{ }^{\circ} \mathrm{C} / \mathrm{SEC}$ fire, concrete spalling was not observed due to the relatively low heating ratio and low temperature in the furnace. As shown in Fig.9., although the temperature rose over the permissible limit of $380^{\circ} \mathrm{C}$ in the range of $5 \sim 20 \mathrm{~mm}$ from the heating surface, spalling did not occur thanks to relatively slower temperature rise.

In the RWS fire, rapid rise in temperature in the 5 $30 \mathrm{~mm}$ range from the heating surface caused spalling and the damage to the overall concrete surface resulted 

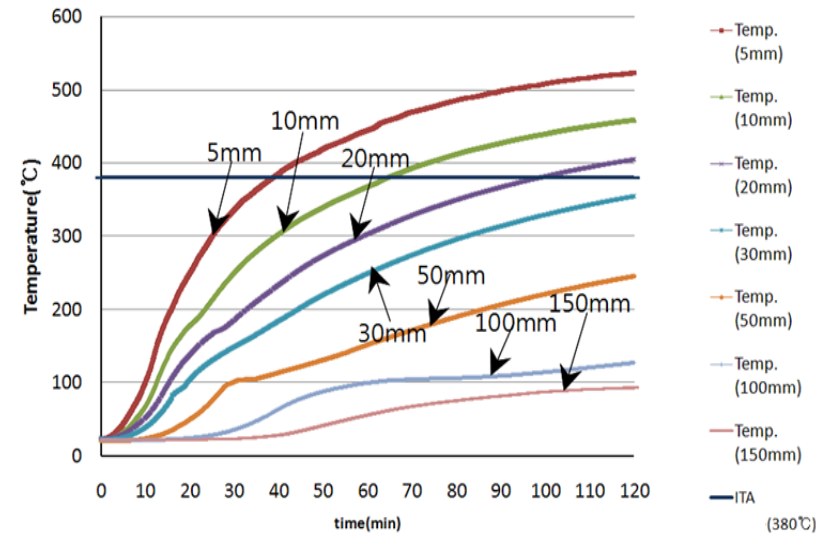

Fig.9. Fire Damage Range by $1^{\circ} \mathrm{C} / \mathrm{SEC}$ Fire $\left(380^{\circ} \mathrm{C}\right)$

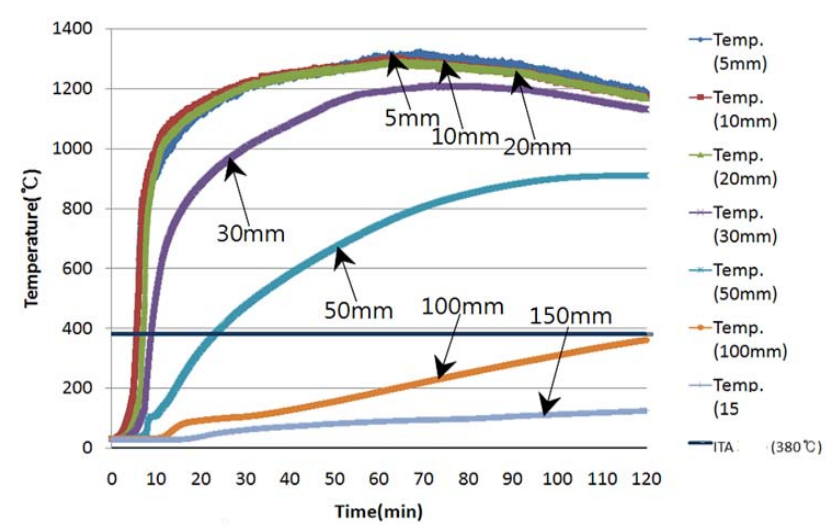

Fig.10. Fire Damage Range by RWS Fire $\left(380^{\circ} \mathrm{C}\right)$

in a temperature rise even at the $50 \mathrm{~mm}$ point from the heating surface. Spalling was observed mainly at around 10 minutes. As shown in Fig.10., capacity deterioration was feasible at a depth of $50 \mathrm{~mm}$ from the heating surface where the temperature rose over the ITA permissible limit of $380^{\circ} \mathrm{C}$.

\subsection{Thermal damage and spalling associated with load ratio}

A fire test for $24 \mathrm{MPa}$ concrete was conducted as follows to identify the influence of load ratio on spalling and find the ultimate load ratio causing the deterioration in concrete strength and the failure of concrete lining.

\subsubsection{Influence on spalling and cracks}

Before the heating test, load was applied to a $150 \mathrm{~mm} \times 600 \mathrm{~mm}$ sectional area of each specimen at a speed of $30 \mathrm{~N} / \mathrm{min}$ until the target load ratio was reached. Load remained constant after that. The MHC fire was applied for 120 minutes to one side direction. It is deduced that the appropriate load generates micro cracks and promotes moisture flow to control spalling, whereas too heavy load causes strength deterioration and spalling. Under a load ratio of $70 \%$, concrete lining was destroyed as soon as heating was applied.

Table 8 . shows spalling and crack details. The result in which spalling occurred under a load ratio of $0 \%$ while not under a load ratio of $20 \%$ and $40 \%$ corresponds to that of the study conducted by the
Table 8. Test Results of Spalling and Crack

\begin{tabular}{|c|c|c|c|}
\hline Specimen & $\begin{array}{l}\begin{array}{l}\text { Strength } \\
\text { (MPa) }\end{array} \\
\end{array}$ & $\begin{array}{c}\text { Spalling depth } \\
(\mathrm{mm})\end{array}$ & $\begin{array}{c}\text { Crack } \\
(\mathrm{mm})\end{array}$ \\
\hline I-M-1 & \multirow{5}{*}{24} & 16 & 2.0 \\
\hline I-M-2 & & 0 & 0.5 \\
\hline I-M-3 & & 0 & 0.3 \\
\hline I-M-4 & & 24 & 1.0 \\
\hline I-M-5 & & Fracture & - \\
\hline
\end{tabular}

authors of this study. ${ }^{12)}$ In addition, the findings on the relation betweenload and spalling also correspond to those of the study carried out by Phan L.T. ${ }^{13)}$ and Harada K. ${ }^{14)}$.

\subsubsection{Influence on temperature rise}

In the I-M-1 specimen which was under a load ratio of $0 \%$, moisture vaporized into gas in $10 \sim 18$ minutes after heating. Intensive fire caused spalling, the thermo couple at a depth of $10 \mathrm{~mm}$ was exposed and the temperature rose to $1,182^{\circ} \mathrm{C}$. At a depth of $75 \mathrm{~mm}$, the temperature rose to $388^{\circ} \mathrm{C}$. Fig. 11. (a) shows temperature rise in the unstressed heating test. In the I-M-2 specimen, which was under a load ratio of $20 \%$, micro cracks played the role as a passage of moisture, controlled spalling and prevented surface damage. Consequently, temperature rise was not significant. The highest temperature at a depth of $10 \mathrm{~mm}$ from the heating surface was $943^{\circ} \mathrm{C}$ as shown in Fig.11. (b), which was lower than that of $1038^{\circ} \mathrm{C}$ observed at a depth of $20 \mathrm{~mm}$ in the I-M-1 specimen.

In the I-M-3 specimen, which was under a load ratio of $40 \%$, spalling did not occur and the temperature rise pattern was similar to that in specimen I-M-2. In the I-M-4 specimen, which was under a load ratio of $60 \%$, spalling was observed and the temperature rose to $1,064^{\circ} \mathrm{C}$. Temperature rise pattern in the specimen was similar to that in the I-M-1 specimen seemingly because of surface damage caused by spalling.

\section{Conclusion}

The conclusion of the test conducted with variables of fire intensity, compressive strength and load ratio to analyze the thermal damage and spalling of concrete lining is as follows.

1) In the ISO fire, the depth of spalling of the PC panel lining was $10 \mathrm{~mm}$ and thermal damage was caused at a depth of $30 \mathrm{~mm}$ from the surface exposed to a fire. Maximum pore pressure was observed at a depth of $20 \mathrm{~mm}$, spalling occurred at the 20 minute point after heating and the temperature rose to $150 \sim 200{ }^{\circ} \mathrm{C}$.

2) In the MHC fire, the depth of spalling of the PC panel lining was $30 \mathrm{~mm}$ as in the RWS fire and thermal damage was caused at a depth of $100 \mathrm{~mm}$ from the surface exposed to a fire. Pore pressure inside concrete, the cause of spalling, was the strongest at a depth of $40 \mathrm{~mm}$. Spalling occurred at the $15 \sim 30$ minute point after heating when the temperature was $150 \sim 250^{\circ} \mathrm{C}$. 


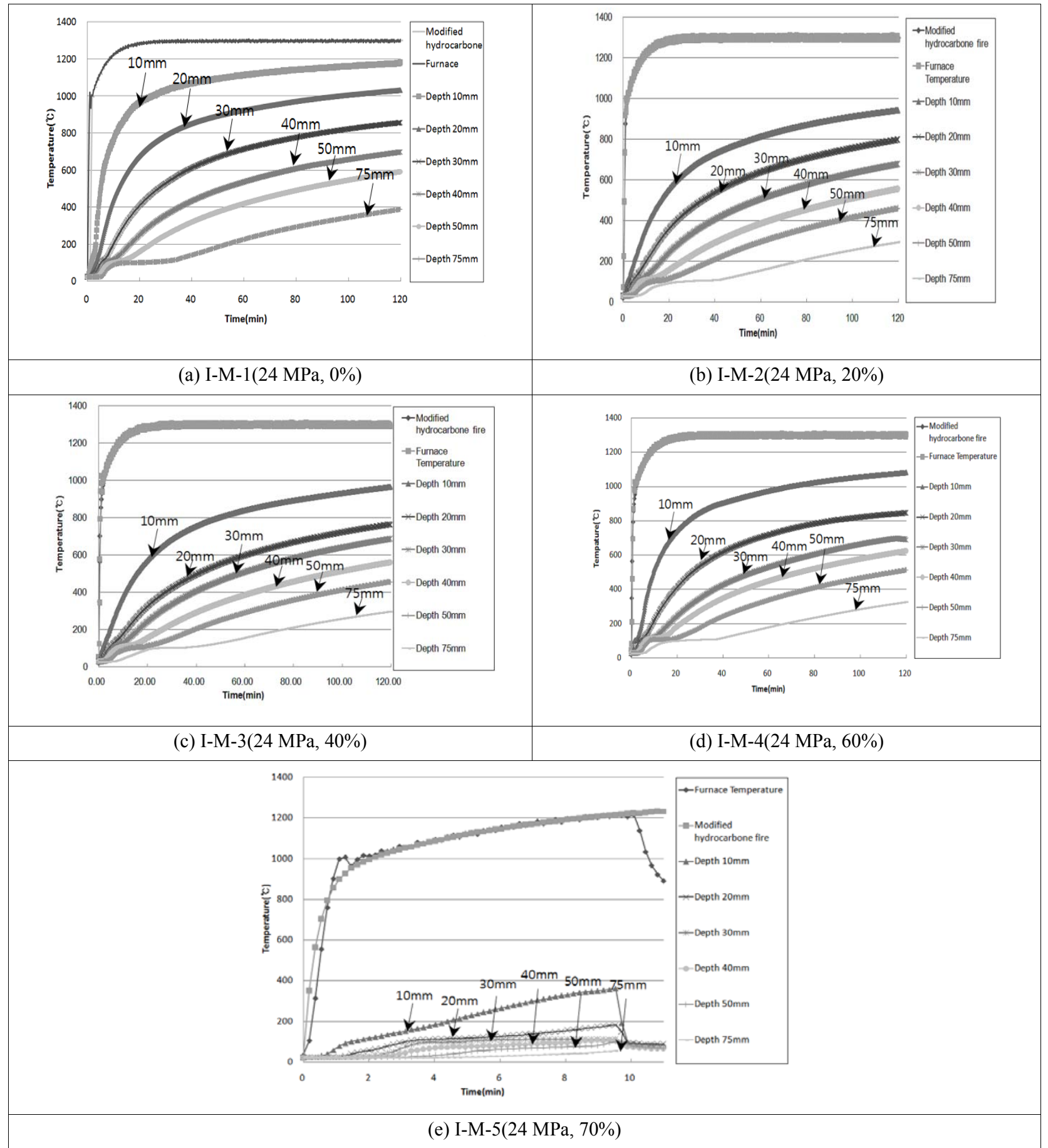

Fig. 11. The Result of Fire Test (Loading: $0 \% \sim 70 \%$ )

3) In the $1^{\circ} \mathrm{C} / \mathrm{Sec}$. fire, while the depth of spalling of the PC panel lining was $0 \mathrm{~mm}$, thermal damage was caused at a depth of $20 \mathrm{~mm}$ from the surface exposed to a fire.

4) In the RWS fire, while the depth of spalling of the PC panel lining was $30 \mathrm{~mm}$, thermal damage was caused at a depth of $50 \mathrm{~mm}$ from the surface exposed to a fire.

5) Appropriate load ratio generated micro cracks inside concrete, lowered pore pressure and mitigated spalling.
6) Increase in load ratio accelerated temperature rise. Load ratio of over $70 \%$ of the sectional strength of concrete lining caused rapid rupture.

\section{Acknowledgments}

This study was conducted as part of "An Advanced Study on Performance-Based Fire Safety of Structures in Fire[2011]" Project sponsored by the Korea Institute of Construction Technology. 


\section{References}

1) The Ministry of Land, Transport, and Maritime Affairs, "Final Report on the technical development of Fire-resistant elements for Tunnel Structures", Korea Institute of Construction Technology, pp.15-21, (2008).

2) Hyung Jun Kim, "Study on the impact of spalling of concrete component in a fire", a thesis of Korean Institute of Fire Science \& Engineering Vol. 21, No. 2, pp.1-6, (2007).

3) ITA Working Group No. 6, "Guidelines for Structural Fire Resistance for Road Tunnels", International Tunneling Association, ITA, pp.36-41, (2004).

4) World Road Association (PIARC), "PIARC Proposal on Design Criteria for Resistance to Fire for Road Tunnel Structures, Paris, Revision 1, 2002.

5) Korean Standards Association, "Methods of Fire-Resistant Testing for Structural Element - General Requirements (KS F 2257-1)", Korean Industrial Standards, pp.3-13, (1999).

6) EFNARC, Specifications and Guidelines for Testing of Passive Fire Protection for concrete Tunnels Linings, pp.15-27, (2006).

7) The Ministry of Land, Transport, and Maritime Affairs, "Final Report on the technical development of Fire-resistant elements for Tunnel Structures", Korea Institute of Construction Technology, pp.32-35.

8) The Ministry of Land, Transport, and Maritime Affairs, "The Guideline of Tunnel Design", The Ministry of Land, Transport, and Maritime Affairs (2007).

9) Korean Standards Association, "Portland Cement (KS L 5201)", Korean Industrial Standards, pp.1-8, (2006).

10) Heikki Kukko and Hemming Paroll, "Moisture Measurement in Concrete Constructions exposed to Temperature and Moisture Variation", Nordic concrete Federation Mini-Seminar, p.4, (1997).

11) ASTM, "Standard Test Method for Total Evaporable Moisture Content of Aggregate by Drying" ASTM C 566, pp.1-3, (2004).

12) Kim Hyung-jun, Kim Heung-youl, Park Kyung-hoon, Jung JeaYoung, Kwon Gi-hyuk, "An Experimental study on Thermal Damage and Spalling of Concrete Lining in Tunnel Fire, KIFSE Vol. 23, No. 6, pp.66-74, (2009).

13) Phan L.T., Carino N.J., "Effects of test conditions and mixture proportion on behaviours of high-strength concrete exposed to high temperatures", ACI Material Journal (2002).

14) Arita F., Harada K., and Miyamoto K., "Thermal spalling of highperformance concrete during fire", $2^{\text {nd }}$ International Workshop on Structure in Fire, Christchurch March. (2002). 